\title{
Text Creative Reading and the Reform of Modern and Contemporary Chinese Literature Teaching
}

\author{
Disheng Zhang \\ College of Humanities and Fine Arts \\ Xi'an International University \\ Xi’an, China
}

\begin{abstract}
The modern and contemporary Chinese literature, as one of the compulsory courses for Chinese language and literature major, aims to cultivate the student's ability to feel, analyze and appreciate the literature and to improve the student's humanistic quality. The cultivation of the student's ability is inseparable from a large amount of reading, especially text creative reading. This paper studies the reform feasibility of modern and contemporary Chinese literature teaching from two aspects: One is the text creative reading aiming at current problems existing in text reading teaching of modern and contemporary Chinese literature, such as poor reading foundation of the student, unreasonable teaching hour and content, and simple text reading teaching method; the other is the construction of teaching strategy for text creative reading, including teaching idea, classroom teaching model, and creative reading mechanism for extracurricular texts.
\end{abstract}

Keywords-creative reading; modern and contemporary Chinese literature; teaching reform; innovation

\section{INTRODUCTION}

The modern and contemporary Chinese literature, as one of the compulsory courses for Chinese language and literature major, aims to cultivate the student's ability to feel, analyze and appreciate the literature and to improve the student's humanistic quality. The cultivation of the student's ability is inseparable from a large amount of reading, especially text creative reading. Creative reading refers to "Based on text fine reading and feeling, guide the student to pay attention to the multi-intentionality and ambiguity of textual connotation, as well as the time and space openness of art, and encourage the student to give full play to creative imagination to actively and creatively construct the text."[1]. The text reading is an important guarantee to achieve the teaching goal. This paper studies the reform feasibility of modern and contemporary Chinese literature teaching from two aspects: One is the text creative reading aiming at problems existing in text reading teaching of modern and contemporary Chinese literature; the other is the construction of teaching strategy for text creative reading.

\section{Problems Existing In TeXt ReAding TeAching OF MODERN AND CONTEMPORARY CHINESE LITERATURE}

\section{A. The student's reading foundation is poor}

Generally, the courses of modern and contemporary Chinese literature will be set in the first or second academic year, and the student's reading amount during the middle and high school period will directly affect the teaching of modern and contemporary Chinese literature. I ever did a reading survey targeted at 180 freshmen from four Chinese language and literature undergraduate programs, aiming at their reading amount of modern and contemporary Chinese literature works written by famous writers during their middle and high school period.

TABLE I. READING OF MODERN AND CONTEMPORARY CHINESE LITERATURE WORKS WRITTEN BY FAMOUS WRITERS DURING MIDDLE AND HIGH SCHOOL PERIOD

\begin{tabular}{|c|c|c|c|c|c|c|c|}
\hline \multirow{2}{*}{ Content } & \multicolumn{4}{|c|}{ Quantity } & \multicolumn{3}{c|}{$\begin{array}{c}\text { Reading situation (taking representative works of Lu Xun, Guo Moruo, Mao Dun, Ba Jin, Lao She, Cao Yu, } \\
\text { Shen Congwen, Eileen Chang, Mo Yan and Wang Anyi as examples) }\end{array}$} \\
\cline { 2 - 7 } & $1-10$ & $10-25$ & $\begin{array}{c}\text { More } \\
\text { than } 25\end{array}$ & $\begin{array}{c}\text { Only know names of writers and } \\
\text { their works }\end{array}$ & $\begin{array}{c}\text { Know characters of certain } \\
\text { works }\end{array}$ & $\begin{array}{c}\text { Read partial } \\
\text { sections }\end{array}$ & $\begin{array}{c}\text { Read full } \\
\text { text }\end{array}$ \\
\hline $\begin{array}{c}\text { Number of } \\
\text { Freshmen }\end{array}$ & 130 & 32 & 18 & 112 & 25 & 13 \\
\hline Percentage & $72.2 \%$ & $17.8 \%$ & $10.0 \%$ & $62.2 \%$ & $16.7 \%$ & $7.2 \%$ \\
\hline
\end{tabular}

As shown in the table above, the freshmen's reading amount during their middle and high school period is insufficient. Most freshmen read very few modern and contemporary literary works; only $10 \%$ of them read more than 25 books. In addition, the reading quality is not satisfactory, full-text reading only accounting for $8.3 \%$. Most of them only know the names of writers and their works, or have a rough understanding of the stories. They cannot read the text in an individualized and creative way. Therefore, it can be concluded that the student's reading accumulation during the middle and high school period is less, and the student's reading foundation is relatively poor. According to my actual teaching experience, the student's reading foundation and accumulation will directly affect the teaching effect of modern and contemporary Chinese literature. During the teaching process, I find that the student with a good reading foundation is more active during class, and easy to maintain good interaction with the teacher. On the contrary, the student with a poor reading foundation is intended to be inactive during class, and often becomes a bystander during classroom teaching. The student with poor reading 
foundation cannot read text in a perceptual way, and will be easily affected by others during the teaching process. Most of the opinions of such student come from textbooks or on-line articles. There is no innovative thinking, personal feeling or opinion. Such situation is not conducive to the teaching of modern and contemporary Chinese literature.

\section{B. The teaching hour and content are unreasonable}

Firstly, the educational idea of applied talent cultivation is an important talent training model at present. The characteristics of "application" are over-strengthened, and the utilitarian and practicability of education are overemphasized. Under such background, the majors derived from modern and contemporary Chinese literature are diluted, and the value of modern and contemporary Chinese literature is underestimated. We can find that the literature teaching hour is compressed, and the teaching content does not suit the teaching hour. For example, the school where I worked has reduced the teaching time for modern and contemporary Chinese literature from two academic years to one academic year. The total teaching hours have dropped from 258 to 144, and then from 144 to 96. To completing the teaching of literary history and partial writers including their representative works in 96 hours, the content will be inevitably compressed, as well as the total teaching hours for text reading and text appreciation.

Besides, from the aspect of the student, in order to adapt to the application-oriented talent cultivation model and to improve the competitiveness after graduation, the student will spend a lot of time to obtain various certificates. Thus, the reading time of the student will be inevitably reduced. It is difficult for the student to really sit down and spend a lot of time on text reading, even the reading tasks arranged by the teacher cannot be completed in required quality and quantity, not to mention reading in a creative way. I ever researched 180 freshmen from university where I worked for their reading time of modern and contemporary Chinese literature works, and the statistical result is as below:

TABLE II. READING TIME OF MODERN AND CONTEMPORARY CHINESE LITERATURE WORKS

\begin{tabular}{|c|c|c|c|c|c|}
\hline \multirow{2}{*}{ Content } & \multicolumn{5}{|c|}{ Reading Time (h/week) } \\
\cline { 2 - 6 } & $1-4$ & $5-9$ & $10-13$ & $14-18$ & More than 18 \\
\hline Number of Freshmen & 95 & 54 & 21 & 10 & 0 \\
\hline Percentage & $52.8 \%$ & $30.0 \%$ & $11.7 \%$ & $5.6 \%$ & $0.0 \%$ \\
\hline
\end{tabular}

From the statistical result of the table above, most freshmen invest less in the reading of modern and contemporary Chinese literature works, even more than half of them only spend 1-4 hours a week for reading. The freshmen reading more than 10 hours a week is less than $20 \%$. The student's reading time is seriously insufficient; that is to say, the student has not read enough texts. Such text reading time allocation is far from meeting the requirements of current modern and contemporary Chinese literature courses.

\section{The teaching method for text reading is simple}

The traditional teaching method for text reading of modern and contemporary Chinese literature is relatively simple. In text reading teaching process, the teacher is always the leader of text reading, while the student can only passively listen to the teacher's inexhaustible explanation and interpretation of the text. In addition, the teacher tends to focus on text appreciation or text criticizing other than creative reading. Simple teaching method devitalizes the text reading. From the perspective of literature realization theory, the value of literary works cannot be accomplished without the participation of acceptor. "There are a thousand Hamlets in a thousand people's eyes", which must be based on the individualized and creative interpretation of different acceptors. However, the traditional teaching model ignores the subjectivity of the student's active participation in text reading, which makes the student unable to achieve individualized reading. Lacking a unique aesthetic experience, the student cannot feel the aesthetic and artistic charm of the text. Without the individualized reading ability, it is impossible for the student to realize text creative reading. Lacking creative reading of text will inevitably affect the student's literature feeling, aesthetic judgment, creativity, and ability to analyze and solve problems.

\section{CONSTRUCTION OF TEACHING STRATEGY FOR TEXT CREATIVE READING}

Aiming at problems existing in text reading teaching of modern and contemporary Chinese literature, the construction of teaching strategy for "text creative reading" must be focused during the teaching reform of modern and contemporary Chinese literature.

\section{A. Establishing the teaching idea based on text creative reading}

"In a university, if there are only various facts without guide ideas, this university is precarious"[2]. Similarly, modern and contemporary Chinese literature teaching without the idea of text creative reading will lead severe consequence. Therefore, the teaching idea based on text creative reading should be established.

Firstly, the "literary history" teaching should be diluted during teaching process to highlight text creative reading. The traditional teaching of modern and contemporary Chinese literature often focuses on the teaching of literary history knowledge. A large amount of classroom time is used in the construction of the literary history system, which fails to highlight the importance of text creative reading solution in teaching. Therefore, serious consequences may be leaded; for example, the student may not have the ability to interpret and appreciate texts, or to analyze and solve problems. Without effective methods and means for text creative reading, the student's innovative ability cannot be trained. To establish the teaching idea based on text creative reading, the proportion of literary history teaching in classroom should be reduced, and the text creative reading should be emphasized. As to concrete strategy, the form of mind map should be adopted. For each class, the student should pre-learn the knowledge points of the literary history part and make a presentation during class. The teacher only needs to interpret difficult knowledge points. After the class, the student should supplement the mind map. By doing so, a large amount of classroom teaching time can be saved.

There are some examples: a) the teaching of Chapter I The May Forth Literary Revolution: The student should establish 
the mind map according to course content, which shows the background, process, contribution and significance of the literary revolution. During the class, group discussion should be conducted, and the optimal mind map for this chapter should be displayed. The teacher should focus on explanation of student's unclear points and guides the student to think deeply in the form of questions. For example, the question "What's your opinion on the criticizing of traditional culture during the May Fourth Literary Revolution?” can be asked, and the student should think independently and write their individualized opinions down. b) The teaching of Shen Congwen's novel creation: Before the class, the teacher can arrange pre-learning tasks to different study groups, one for collection of Shen Congwen's biographical materials, one for collection of Shen Congwen's literary creation ideas, one for collection of the pictures of Shen Congwen and his works, one for collection of novel Border Town and corresponding film, and one for containing knowledge points of this chapter into one mind map and presenting in class. Then, the teacher should give in-depth explanation based on problems found to guide the student to actively explore, think and solve problems. Meanwhile, the teacher can interpret certain classical text fragments, classical video clips and related pictures of Border Town with different literary criticism methods. After class, the questions or homework that extended classroom teaching content can be arranged, such as: What is Shen Congwen's literary creation thought reflected from Border Town? How to evaluate Shen Congwen's “ideal humanity”? Or the student can be asked to continue novel writing according to the ending of the story.

Secondly, in order to ensure text creative reading teaching activity, the reading list should be given to the student at the very first class. The list should include two parts: classical text reading in the classroom, and extracurricular text reading. The classical texts are used as reading texts in classroom teaching, which the student must familiarize, memorize, and appreciate their classical chapters or fragments. The extracurricular texts are used for the student's extended reading, which the student should read and think individually, write a corresponding reading feeling, and refine own viewpoints. Taking the teaching of Lu Xun's novels as an example, the True Story of $A h Q$ and Diary of a Madman can be listed as classical texts, and the classroom teaching of text creative reading can be designed around these two texts. As to extracurricular reading, Mourning the Passing, Loner, Hometown and Water Conservancy can be listed in as extended reading texts from four aspects: love, peasant, intellectual and historical story. The teacher can assign these four texts to four study groups. Each group should write the reading note, appreciate the text or write after-reading feeling respectively. Combining in-classroom reading and extracurricular reading, the student can complete reading list in required quality according to plan.

\section{B. Establishing two-way thinking type classroom teaching model with multiple teaching methods for text creative reading}

Firstly, the two-way thinking type classroom teaching paradigm should be established.
“Two-way thinking mainly refers to the student's thinking process to interrelate and integrate the intuitive reading feeling and innovative thinking during knowledge acquisition. There are two forms of reading: One is 'primary reading', without any appreciation material, and only intuitive feeling obtained from the works itself"; the other is 'creative' reading, which means the re-learning of connotation, writing techniques, style and framework of the works under the guide of teacher after looking up appreciation materials, doing exercises and the teacher's explanation.[3] The classroom teaching of text creative reading refers to: During the process appreciating and critically interpreting the classical text, the teacher guides the student to complete "primary reading", and the student use two-way thinking to further conduct "text creative reading". The teacher can use different methodologies to analyze literary language, literary conception and literary content, and the student will unconsciously learn the method for text interpretation and feel literary aesthetics. Besides, the introspectiveness of the student can be trained through critical reading. Thus, the student's ability to appreciate and analyze works can be continuously improved, as well as the student's innovation ability. Taking the teaching of Eileen Chang's novel creation as an example, the teacher can arrange the student to read The Golden Cangue and Love in a Fallen City, and to enjoy the movie Lust Caution one week in advance. During classroom, the teacher can guide the student to appreciate and critically read The Golden Cangue in the form of questions such as "What are the characteristics of Cao Qiqiao", "How to evaluate the 'distorted psychology', "What is Eileen Chang's female consciousness?”, "What are the costume images?", and "What is Eileen Chang's creative art style?". The teacher also can combine the novel fragments and video clips to guide the student to appreciate and read The Golden Cangue in a critical and creative way. Besides, the comparative reading of The Golden Cangue and Love in a Fallen City can be conducted. The teacher throws out questions, and the student answers questions according to the text; or the student ask questions, and the teacher gives in-depth explanation. Through such two-way thinking classroom teaching process, the student can learn the method for creative reading. After class, the teacher can require the student to read Heart Sutra, and use the "Oedipus" complex theory in Freudianism to creatively read the text. The student can write own feeling and experience into an article, and the teacher and student can jointly evaluate such article in groups. By doing so, a two-way thinking classroom teaching model can be formed.

Secondly, the classroom discussion type teaching for text creative reading should be established.

The traditional classroom teaching of text reading adopts cramming teaching method, which suppresses the enthusiasm, initiative and innovation of the student. At present, however, the society requires the talents cultivated by the university should be innovative and creative. Therefore, the traditional teaching method for text reading must be reformed. The classroom discussion, as a good teaching method, is a strong guarantee for text creative reading model establishment.

The classroom discussion type method refers to: During the classroom teaching process, the teacher and student discuss a certain problem in a limited time and space. Then the student 
clarifies own views, and the teacher makes comments. The advantages of this teaching method are: The student's individualized reading experience is paid attention to during the teaching process; the student's ability to think independently can be cultivated; the student's ability to analyze and solve problems can be improved; the student's creative spirit can be finally formed. Group-based classroom discussion teaching can cultivate the student's ability of cooperation and reasonable allocation. The classroom discussion type teaching is based on adequate preparation, including the questions to be discussed, question difficulty design, the purpose of the discussion, etc. The teacher must make a reasonable design by combining the student's current situation. Meanwhile, the student must master the bibliography and reference arranged by the teacher. The classroom discussion type teaching has high requirements for both the teacher and student. During discussion, the teacher should find the problems and communicate with the student in time to solve the problems. The teacher should timely and appropriately guide the discussion of the student to ensure that the discussion is closely focused on the questions and to prevent deviation and invalid discussion. In addition, the discussion form can be a group discussion or whole class discussion. Regardless of the form, the teacher should be dominated, and the student shall be the main body. The teacher and student should listen to different opinions from each other. The teacher should encourage and guide the student to solve problems. Particularly, the teacher must respect the individualized viewpoints, feelings and experiences of the student.

Thirdly, the classroom teaching method for text creative reading dominated by network and multimedia technology should be established.

The text creative reading teaching faces the challenges from many new teaching methods, "such as flipped class, micro-class, MOOCs, etc. The development of new network technology has created an era of highly developed information and convenient use of information." [4] The teacher should adapt to the requirements on teaching by the new era and create a lively text creative reading classroom teaching.

Text acquisition during teaching process: The network and multimedia provide us with many electronic texts, pictures, videos, audios and research materials, which can be directly downloaded and applied to the teaching and provide huge data support for the teaching. For teaching material acquisition, the network and multimedia technology has broken through the singularity and narrowness of the traditional means.

The teacher can, through network technology, integrate the teaching resources for text creative reading. The teacher can reasonably arrange the texts, pictures, videos and audios centered on the teaching content to enable the student fully mobilize their visual, auditory and other sensory systems during the process of text creative reading. By accepting many information shocks, the student can realize perceptual cognition, rational thinking and creative imagination. Taking the creative reading of The Golden Cangue written by Eileen Chang as an example, relevant knowledge points can be contained in a PPT including the texts, the pictures of Cao Qiqiao and other characters, video clips, theme song, excellent courses or MOOCs related to The Golden Cangue, etc. During the teaching process, the teacher can show rich teaching materials to the student, and the student can achieve primary reading through listening, watching and the teacher's explanation. During the discussion, the student can think and generate own viewpoints according to problems found during learning process.

\section{Strengthening the creative reading guidance of} extracurricular texts and establish a creative reading mechanism for the creative reading of extracurricular texts

"The reading history of a nation is its mental development history. Similarly, a person's reading history is his/her mental history".[5] Text creative reading is conducive to improve the student's innovative ability. The teacher should guide the student to establish a long-term text creative reading mechanism, which can help the student develop creative reading habit. The teacher can guide the student to use the library and network resources for text reading activities, strengthen the reading of classical texts, carry out reading communication activities to cultivate the student's good reading habit. Besides, school resources can be utilized to actively encourage the student to participate in lectures by famous writers, critics, and scholars, to expand the student's knowledge and to stimulate the student's reading enthusiasm. Routinizing the student's text creative reading can make it become an important part of the student's daily life. The student can improve own literary quality through daily activities, such as participating in poetry reading, modern and contemporary drama rehearsing, and watching the films adapted from modern and contemporary novels.

\section{CONCLUSION}

In conclusion, "the implementation of text creative reading teaching model is an important breakthrough for the reform of modern and contemporary Chinese literature teaching."[6] The establishment of text creative reading teaching model will energize the modern and contemporary Chinese literature, cultivate student with innovative spirit and creativity, and make the teaching of modern and contemporary Chinese literature a powerful platform for talent cultivation.

\section{REFERENCES}

[1] Xianghua Zhou, "Classical Text Reading and the Reform of Modern and Contemporary Chinese Literature Teaching”, Journal of Putian University, 2018, (3) (In Chinese)

[2] [German] Karl Jaspers, Libo Qiu Trans. The Idea of the University. Shanghai: People's Publishing House, 2007:71

[3] Wenping Yuan, "Current Situation and the Reform Exploration of Modern and Contemporary Chinese Literature Courses”, Language Planning, 2017, (11) (In Chinese)

[4] Ronghu Yu, “The Challenges and Strategies of Modern and Contemporary Chinese Literature Teaching Facing New Network Technology”, Journal of Nanjing Xiaozhuang University, 2018, (01) (In Chinese)

[5] Li Lin, Humanity Reading and Writing. Nanjing: Nanjing University Press, 2006:8 (In Chinese)

[6] Ying Yan, The Construction and Reform of Fine Courses for Modern and Contemporary Chinese Literature, Education Teaching Forum, 2016 , (12) 